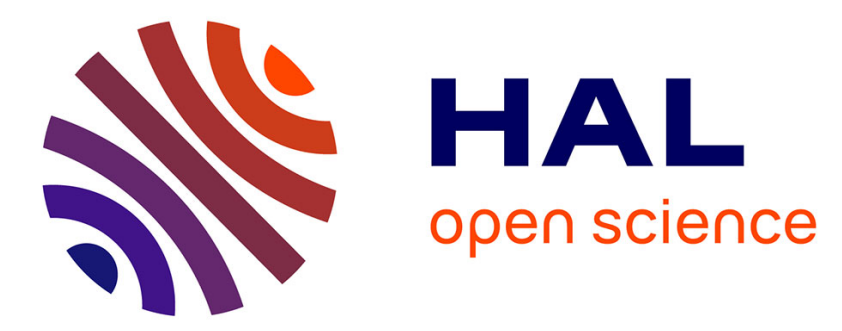

\title{
Factors limiting the grain protein content of organic winter wheat in south-eastern France: a mixed-model approach
}

Marion Casagrande, Christophe David, Muriel Valantin-Morison, David Makowski, Marie-Hélène Jeuffroy

\section{To cite this version:}

Marion Casagrande, Christophe David, Muriel Valantin-Morison, David Makowski, Marie-Hélène Jeuffroy. Factors limiting the grain protein content of organic winter wheat in south-eastern France: a mixed-model approach. Agronomy for Sustainable Development, 2009, 29 (4), pp.565-574. 10.1051/agro/2009015 . hal-00886484

\section{HAL Id: hal-00886484 https://hal.science/hal-00886484}

Submitted on 1 Jan 2009

HAL is a multi-disciplinary open access archive for the deposit and dissemination of scientific research documents, whether they are published or not. The documents may come from teaching and research institutions in France or abroad, or from public or private research centers.
L'archive ouverte pluridisciplinaire HAL, est destinée au dépôt et à la diffusion de documents scientifiques de niveau recherche, publiés ou non, émanant des établissements d'enseignement et de recherche français ou étrangers, des laboratoires publics ou privés.

$$
\text { Copyright }
$$




\title{
Factors limiting the grain protein content of organic winter wheat in south-eastern France: a mixed-model approach
}

\author{
Marion CASAGRANDE ${ }^{1 *}$, Christophe DAVID ${ }^{2}$, Muriel VAlANTIN-Morison ${ }^{1}$, David MAKowsKi $^{1}$, \\ Marie-Hélène JEUFFROY ${ }^{1}$ \\ ${ }^{1}$ INRA, UMR211 INRA/AgroParisTech, 78850 Thiverval-Grignon, France \\ ${ }^{2}$ Université Lyon, ISARA-Lyon, 23 Rue Jean Baldassini, 69364 Lyon Cedex 07, France
}

(Accepted 24 April 2009)

\begin{abstract}
Organic agriculture could achieve the objectives of sustainable agriculture by banning the use of synthetic fertilizers and pesticides. However, organic crops generally show lower performances than conventional ones. In France, organic winter wheat production is characterized by low grain protein content. There is a crucial need for better understanding the variability of grain protein content, because millers require batches with values over $10.5 \%$ of dry matter. Here, a regional agronomic diagnosis was carried out to identify the limiting factors and crop management practices explaining the variability of grain protein content. The studied field network was a set of 51 organic winter wheat plots in south-eastern France. The mixed-model method was used for identifying and ranking the limiting factors and the crop management practices responsible for variation in limiting factors. Our results show that the grain protein content variation was mostly explained by the baking quality grade of the cultivar, crop nitrogen status and weed density at flowering. There was a positive correlation between grain protein content and both crop nitrogen status and weed density. To a lesser extent, climatic factors also explained grain protein content variability. A lower water stress increased grain protein content, whereas an increase in the photothermal quotient and daily temperature over $25^{\circ} \mathrm{C}$ reduced grain protein content. In south-eastern France, grain protein content of organic winter wheat could be increased by improving fertilization management, using an improved baking quality grade cultivar, choosing a legume fodder crop as preceding crop, or by avoiding late sowing dates.
\end{abstract}

agronomic diagnosis / crop management / grain protein content / mixed-model / organic farming / winter wheat

\section{INTRODUCTION}

Sustainable agricultural development aims at increasing the productivity and quality of crop production, while decreasing its harmful environmental impacts (Tilman et al., 2002). These objectives can be partially achieved by using organic farming practices which ban the use of synthetic fertilizers and pesticides. Organic agriculture generally leads to lower grain yields (Mäder et al., 2002) but provides better environmental and socio-economic benefits compared with conventional agriculture (Reganold et al., 2001). However, further research is required to improve the performance of organic farming as well as to guarantee environmental sustainability (e.g. protection of water resources and biodiversity, and mitigation of climate change). The recent growth in the or-

\footnotetext{
* Corresponding author: marion.casagrande@wur.nl

Present address: Biological Farming Systems Group, Wageningen University, PO Box 563, 6700 AN Wageningen, The Netherlands.
}

ganic food market in Europe is mainly due to large retailers responding to an increase in consumer demand. In response to this increase, further food quality and safety requirements have been established. For instance, the minimum threshold required for wheat grain protein content (GPC) was recently increased from 9 to $10.5 \%$ of grain dry matter for organic breadmaking wheat in France (David et al., 2007). Therefore, the price paid to farmers by grain processors is now frequently dependent on the grain protein content.

In Europe, organic winter wheat (Triticum aestivum L.) production is characterized by low and variable grain yields and grain protein contents (Gooding et al., 1993; David et al., 2005; Lueck et al., 2006). Previous analytical experiments showed that the crop nitrogen supply can influence the grain protein content (Lueck et al., 2006). Knowing the negative relationship existing between grain yield and GPC (Fowler, 2003), factors affecting grain yield could be expected to have an effect on GPC. Thus, weeds (Bond and Grundy, 2001), pests and diseases (van Bruggen, 1995; Wilkinson et al., 
Table I. Climatic conditions from sowing to harvest within the three studied sub-areas Diois, Plain of Lyon and Plain of Valence; minimum, maximum, and mean values computed for 1994, 1995, 2000, 2004, 2005 and 2006. Values were computed from the 51 studied fields.

\begin{tabular}{|c|c|c|c|c|c|}
\hline Variable & Sub-area & $\begin{array}{c}\text { Minimum } \\
\text { value }\end{array}$ & $\begin{array}{l}\text { Maximum } \\
\text { value }\end{array}$ & $\begin{array}{l}\text { Mean } \\
\text { value }\end{array}$ & $\begin{array}{c}\text { Median } \\
\text { value }\end{array}$ \\
\hline \multirow{3}{*}{ Cumulative rainfall (mm) } & Diois & 533 & 924 & 695 & 641 \\
\hline & Plain of Lyon & 504 & 770 & 623 & 574 \\
\hline & Plain of Valence & 242 & 706 & 497 & 531 \\
\hline \multirow{3}{*}{ Cumulative temperature (degree-days) } & Diois & 2145 & 3152 & 2641 & 2637 \\
\hline & Plain of Lyon & 2449 & 2974 & 2758 & 2780 \\
\hline & Plain of Valence & 2104 & 2892 & 2498 & 2550 \\
\hline \multirow{3}{*}{ Cumulative radiation $\left(\mathrm{J} . \mathrm{cm}^{-2}\right)$} & Diois & 2790 & 3486 & 3109 & 3099 \\
\hline & Plain of Lyon & 2541 & 2933 & 2741 & 2734 \\
\hline & Plain of Valence & 2631 & 3264 & 2957 & 3034 \\
\hline
\end{tabular}

2006), and soil compaction (Peigné et al., 2007) could be expected to have an effect on grain protein content. However, as there have been no studies on the cumulative effect of agronomic and environmental limiting factors on grain protein content, there is a crucial need to identify the most important limiting factors occurring on farmers' fields and to quantify their cumulative effects on grain protein content.

The Regional Agronomic Diagnosis (RAD) is an appropriate method for identifying and ranking the factors limiting crop performances, from data collected in farmers' fields located in a region of interest (Doré et al., 1997). It consists of two steps: (i) identifying and ranking the agronomic and environmental factors explaining low crop performance, and, in turn, (ii) identifying the characteristics of crop management and environment linked to these limiting factors. The RAD methodology has already been applied on cereal crops such as conventional (Leterme et al., 1994) and organic (David et al., 2005) winter wheat, and conventional barley (Le Bail and Meynard, 2003). The purpose of these studies was to explain yield or grain protein content levels and to propose changes in agricultural practices to avoid limiting factors. Except in Le Bail and Meynard (2003), no variable characterizing grain quality has been detected by RAD although grain protein content has become an important criterion for breadmaking wheat.

Most of these diagnostic analyses are based on linear regressions and stepwise selection (Le Bail and Meynard, 2003; David et al., 2005). These statistical techniques are also frequently used in ecology (Whittingham et al., 2006). The main value of stepwise selection is that it can be used to select a subset of explanatory variables by using statistical criteria computed from a dataset, such as the Akaike Information Criteria, the Bayesian Information Criteria, or Fisher statistical tests. The number of explanatory variables and parameters in the final model retained with this procedure is expected to be less than in the full model, and the variance of the estimated parameters can also be reduced. However, several studies (Burnham and Anderson, 2002; Whittingham et al., 2006) have emphasized the limitation of stepwise selection. An important problem is that the uncertainty of the results of the selection method is generally ignored. All inferences are usually made using the selected model only, although the selected set of explanatory variables may be highly sensitive to the dataset used to perform the selection. Thus, a small change in the dataset may lead to a different set of selected variables.

Several statisticians have emphasized that it can be better to mix all models than to use the single selected model, especially when there is a certain degree of uncertainty in choosing the best model (Burnham and Anderson, 2002). The basic idea is to use a weighted mean of the individual model predictions instead of the prediction derived from the single 'best' model. The mixed-model method can improve the accuracy of model predictions and of parameter estimation, and give more realistic confidence intervals.

Here, we identified and ranked the main limiting factors of grain protein content of organic winter wheat in south-eastern France, using the regional agronomic diagnosis approach and a mixed-model method, and we determined the characteristics of the crop management explaining the occurrence of these limiting factors.

\section{MATERIALS AND METHODS}

\subsection{Data}

Data were collected in 51 winter wheat fields located on 25 organic farms in the Rhône-Alpes region, the third largest region for organic farmland in France. Fields were located within a $10800-\mathrm{km}^{2}$ area ranging from $44^{\circ} 22^{\prime}$ to $45^{\circ} 55^{\prime} \mathrm{N}$ and from $4^{\circ} 41^{\prime}$ to $5^{\circ} 25^{\prime} \mathrm{E}$ in south-eastern France. Three subareas can be distinguished: the Diois region, a hilly sub-area near the mountainous area of Vercors, and two plain sub-areas, the Plain of Lyon and the Plain of Valence, respectively, in the north and south part of the region. The field survey was carried out during six growing seasons, between 1994 and 2006, characterized by contrasting weather conditions over years and sub-areas (Tab. I). Distances between the experimental plots and the closest weather station were lower than $25 \mathrm{~km}$. Daily mean temperature, rainfall, radiation and potential crop evapotranspiration were recorded for each field and year. Fields were also characterized by various soil types including calcareous soils classified as sandy clay loam, silt loam or sandy loam (soil A, 29\% of the fields); deep soils classified as silt loam or silty clay loam (soil B, $12 \%$ of the fields); deep and calcareous silt soils (soil C, 39\% of the fields); and calcareous stony clay soils (soil D, $20 \%$ of the fields). 
The organic wheat fields were selected to cover a wide range of cropping systems including different crop management strategies. Farms were selected to represent the three main cropping systems of the region (David et al., 2007). Twenty-seven percent of the fields in the survey were referred to as system 1: mixed farms with crop rotation including almost $60 \%$ of fodder legumes as preceding crops of wheat, using their own organic manure with an average nitrogen input of $53 \mathrm{~kg} \mathrm{~N} \cdot \mathrm{ha}^{-1}$. Fifty-nine percent of the fields were referred to as system 2: intensive grain growers that produce cereals using output organic fertilizer with an average nitrogen input of $67 \mathrm{~kg} \mathrm{~N} . \mathrm{ha}^{-1}$, and include fodder legumes (10\% of wheat preceding crops), grain legumes (35\% of wheat preceding crops), and spring crops such as soybean, sunflower or maize. Fourteen percent of the fields were referred to as system 3: extensive mixed or arable farms that produce cereals with a limited average nitrogen input ( $\left.37 \mathrm{~kg} \mathrm{~N} \cdot \mathrm{ha}^{-1}\right)$, and include fodder legumes (10\% of wheat preceding crops), grain legumes (20\% of wheat preceding crops) and spring crops.

The wheat cultivars grown in the 51 organic fields were Aztec, Caphorn, Florence Aurore, Lona, Orpic, Renan, Sidéral and Soissons. These cultivars differed in their baking quality grades and hence in their potential grain protein content values: $63 \%$ of the fields were sown with superior cultivars, i.e. higher-yielding cultivars, with low grain protein content, whereas $37 \%$ of the fields were sown with improved cultivars with higher grain protein content. Cultivars also differed according to their earliness at heading, i.e. early or late.

The crop management techniques used by the farmers were surveyed. The preceding crop was broken down into three classes: spring crop (47\% of the fields), winter crop (27.5\% of the fields) and fodder legume crop (25.5\% of the fields). These three classes were assumed to influence the weed population in the succeeding wheat crop as well as the type and number of weeding operations (hoeing or harrowing) (Bond and Grundy, 2001). The number of mechanical soil tillage operations before sowing was counted, ranging from 0 to 5 . The sowing date was broken down into three classes, taking into account the weather conditions of the three sub-areas: early (31\% of the fields), optimum (22\% of the fields) or late ( $47 \%$ of the fields) (David et al., 2007). In the Plain of Lyon and the Plain of Valence, sowing date was considered as early before the 27 th of October, as optimum between the 27th of October and the 6th of November, and as late after the 6th of November. In the Diois, sowing date was considered as early before the 5th of October, as optimum between 5th and 15th of October, and as late after the 15 th of October.

The organic nitrogen fertilizer rate, i.e. the amount of $\mathrm{N}$ applied in $\mathrm{kg} \mathrm{ha}^{-1}$, was calculated with regard to the type of fertilizer applied during autumn and/or springtime. The total $\mathrm{N}$ applied was calculated from the amount of organic fertilizer or manure (expressed in kg.ha ${ }^{-1}$ ) multiplied by standardized nitrogen content (expressed in $\mathrm{kg} \mathrm{N} \cdot \mathrm{t}^{-1}$ ) for each type of fertilizer or manure $\left(22 \mathrm{~kg} \mathrm{~N} \cdot \mathrm{t}^{-1}\right.$ for chicken manure, $7 \mathrm{~kg} \mathrm{~N} \cdot \mathrm{t}^{-1}$ for sheep manure, $5.5 \mathrm{~kg} \mathrm{~N} . \mathrm{t}^{-1}$ for cattle manure, $7.2 \mathrm{~kg} \mathrm{~N} . \mathrm{t}^{-1}$ for goat manure and $14 \mathrm{~kg} \mathrm{~N} \cdot \mathrm{t}^{-1}$ for pig bristles). Within the field network, the applied nitrogen supply ranged from 0 to $264 \mathrm{~kg} \mathrm{~N} \cdot \mathrm{ha}^{-1}$. The presence of late spring fertilization, ap- plied after the 1st of April, was surveyed (presence of late spring fertilization: $76.5 \%$ of the fields) knowing the potential positive effect of late applications of $\mathrm{N}$ fertilizers on grain protein content as reported by Debaeke et al. (1996). Weed control during the crop cycle was characterized by the number of mechanical weeding operations with a spring-tine harrow after sowing and ranged from 0 to 3 .

\subsection{Grain yield and grain protein content}

A uniform plot (1000 to $2000 \mathrm{~m}^{2}$ ) was selected on each field to avoid intra-field variability in terms of soil type, wheat development and weed infestation. All measurements were made within these plots. Grain yield and grain N content were determined at maturity from a set of, on average, six $0.25 \mathrm{~m}^{2}$ subplots per plot. Grain yield was standardized at $15 \%$ moisture content after oven-drying at $80{ }^{\circ} \mathrm{C}$ for 48 hours. The $\mathrm{N}$ content of the grains, measured by the Dumas method, allowed the calculation of grain protein content in percentage of dry matter (\% dm), by multiplying it by 5.7 (Grundy et al., 1996).

\subsection{Indicators of limiting factors}

Seven indicators of potential agronomic or environmental limiting factors were chosen to explain grain protein content variability.

\subsubsection{Water balance}

The dynamic water balance was calculated on a daily basis, from flowering to harvest, as the difference between actual evapotranspiration $\left(\mathrm{mm}_{\mathrm{day}}{ }^{-1}\right)$ and maximal crop evapotran-

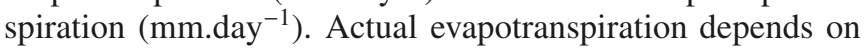
soil water availability $(\mathrm{mm})$, which itself depends on rainfall $(\mathrm{mm})$, irrigation $(\mathrm{mm})$ and soil available water capacity $(\mathrm{mm})$. Soil water availability was calculated thanks to the maximal root depth of the crop measured in each plot and the textural characteristics of each soil. Maximal evapotranspiration was calculated as the product of the potential crop evapotranspiration $\left(m m . d a y^{-1}\right)$ and the cultural crop coefficient, which varied during crop growth according to the development stage (Brisson et al., 1992). The calculation was initiated at sowing time on each field, assuming the soil water availability at that time as nil.

\subsubsection{Photothermal quotient and thermal stress}

Temperature has a positive effect on biomass and $\mathrm{N}$ accumulation in grains during grain filling (Sofield et al., 1977). However, above a certain threshold (defined by various authors between 20 and $30{ }^{\circ} \mathrm{C}$ ), high mean temperatures limit biomass accumulation in grains (Bhullar and Jenner, 1985), leading to an increase in grain protein content by a concentration effect. During grain filling, the amount of incident solar radiation directly affects biomass accumulation, and thus 
may affect grain weight and/or grain protein content (Singh and Jenner, 1984). We therefore calculated the photothermal quotient, the ratio of mean daily solar radiation to mean daily temperature in $\mathrm{J}_{\mathrm{cm}} \mathrm{cm}^{-2} \cdot{ }^{\circ} \mathrm{C}^{-1}$. day ${ }^{-1}$ (Fischer, 1985), for the first 30 days after flowering. This period characterizes the beginning of the grain-filling period. The number of days with a mean temperature above $25^{\circ} \mathrm{C}$ between flowering and harvest was also determined.

\subsubsection{Soil compaction}

A soil profile trench, perpendicular to the direction of ploughing and $3-\mathrm{m}$ long $\times 2-\mathrm{m}$ wide by $1.5-\mathrm{m}$ deep, was examined around the flowering stage in each field near the zones of plant sampling to assess the soil structure and maximal rooting depth. The soil structure was assessed from the clod size distribution and internal structural porosity (Gautronneau and Manichon, 1987). Based on that assessment, the soil structure of each field was classified as either favorable (non-compacted internal state and open clod distribution) or unfavorable (compacted internal state and compacted distribution) structure.

\subsubsection{Nitrogen nutrition}

The Nitrogen Nutrition Index (NNI) is a good indicator of crop nitrogen status to identify crop $\mathrm{N}$ deficiency (Justes et al., 1997). This indicator is known to be positively correlated to grain protein content (Debaeke et al., 1996; Justes et al., 1997). It was calculated using the critical nitrogen curve established by Justes et al. (1997). At flowering, aboveground biomass and its total $\mathrm{N}$ content were determined for an average of four $0.25 \mathrm{~m}^{2}$ sub-plots per plot. The $\mathrm{N}$ concentration of the samples, previously oven-dried, weighed and ground, was determined by the Dumas method.

\subsubsection{Weeds}

Knowing the injurious effect of weed density on grain yield (Cousens, 1985) and on kernel number (David et al., 2005) and expecting an effect on GPC, the total number of weeds was counted at the flowering stage (in plants. $\mathrm{m}^{-2}$ ) on a minimum of four random sub-plots of $0.25 \mathrm{~m}^{2}$ each and then averaged for each field.

\subsubsection{Foliar Diseases}

The incidence of leaf diseases (Septoria spp., Erysiphe graminis and Puccinia triticina) was assessed between flowering and the soft dough stage on the upper two leaves of 20 randomly selected plants per field. Leaf diseases were assessed by estimating by eye the overall percentage of leaf area affected, from $0 \%$ to $100 \%$, as those diseases are known to reduce green leaf area (Audsley et al., 2005).

\subsection{Statistical analysis}

Two types of analysis were performed. First, grain protein content was related to the candidate explanatory variables using linear regression models defined by

$$
y=\theta_{0}+\theta_{1} x_{1}+\ldots+\theta_{p} x_{p}+\varepsilon
$$

where $x_{1}, \ldots, \mathrm{x}_{p}$ are the explanatory variables (indicators of the limiting factors), $\theta_{0}, \ldots, \theta_{p}$ are the model parameters, and $\varepsilon$ is the residual error term. Eight explanative variables were used for the calculation: the baking quality grade, the water balance, the photothermal quotient, the number of days with a mean temperature above $25^{\circ} \mathrm{C}$, the nitrogen nutrition index, the foliar diseases, the weed density and the soil structure.

The mixed-model method (Burnham and Anderson, 2002) consists of fitting all possible linear combinations of the explanatory variables by least squares and in computing, for each combination, the Akaïk Information Criterion (AIC) value (Akaïke, 1974), and the Akaïke weight (Burnham and Anderson, 2002). When $k$ explanatory variables were available, $2^{k}$ variable combinations, and so $2^{k}$ regression models, were fitted. The Akaïke weight was computed for each $i$ th regression model as:

$$
w_{i}=\frac{e^{-0.5\left(A I C_{i}-A I C_{\min }\right)}}{\sum_{i=1}^{n} e^{-0.5\left(A I C_{i}-A I C_{\min }\right)}}
$$

where $w_{i}$ is the weight obtained for the $i$ th combination of explanatory variables, $\mathrm{AIC}_{i}$ is the $\mathrm{AIC}$ value obtained for the corresponding regression model, and $\mathrm{AIC}_{\min }$ is the minimal $\mathrm{AIC}$ value obtained among the $N=2^{k}$ tested combinations. The weight $w_{i}$ is the probability that, given a set of models, model $i$ would be the AIC-best model (Burnham and Anderson, 2002). All the models were averaged using their Akaïke weight. Estimates of the relative importance of the variable $x$ can be made by summing the Akaïke weights across all models in the set where this variable occurs. The relative importance of $x$ is reflected by the sum of these weights, noted $w_{+}(x)$. The larger the $w_{+}(x)$ the more important $x$ is (Burnham and Anderson, 2002). Using these sums, all the variables can be ranked according to their importance.

In a second step, the limiting factors selected in the first step were explained by the crop management techniques and the environmental conditions such as soil type or sub-area. For each previously identified limiting factor, a linear mixedeffects model (with years as a random effect) was defined to relate the limiting factor to the crop management techniques and environmental conditions (including location) (Pinheiro and Bates, 2000). The model was fitted to the data and was compared with a linear regression model without any random effect. When the linear mixed-effects model had the lowest AIC, i.e. when there was a significant year effect, the mixedmodel method described above was implemented with the series of linear mixed-effects models resulting from all the possible linear combinations of crop management techniques and environmental conditions. When the lowest AIC was reached 
Table II. Values of grain yield, grain protein content, and of the quantitative limiting factor indicators.

\begin{tabular}{|c|c|c|c|c|}
\hline Variable & $\begin{array}{l}\text { Minimum } \\
\text { value }\end{array}$ & $\begin{array}{l}\text { Maximum } \\
\text { value }\end{array}$ & $\begin{array}{l}\text { Mean } \\
\text { value }\end{array}$ & $\begin{array}{c}\text { Median } \\
\text { value }\end{array}$ \\
\hline Grain yield (t.ha $\left.{ }^{-1}\right)$ & 1.3 & 7.4 & 4.3 & 4.2 \\
\hline Grain protein content $(\% \mathrm{dm})$ & 7.8 & 15.9 & 10.8 & 10.2 \\
\hline Nitrogen nutrition index at flowering & 0.25 & 0.71 & 0.5 & 0.5 \\
\hline Weed density (plants. $\mathrm{m}^{2}$ ) & 0.0 & 566.9 & 104.9 & 67.0 \\
\hline Water balance from flowering to harvest (mm) & -213.0 & 0.0 & -68.4 & -66.6 \\
\hline Photothermal quotient after flowering $\left(\mathrm{J} . \mathrm{cm}^{-2} .{ }^{\circ} \mathrm{C}^{-1} \cdot \mathrm{day}^{-1}\right)$ & 0.8 & 1.4 & 1.1 & 1.2 \\
\hline Percentage of leaf area affected by foliar diseases (\%) & 0.0 & 90.0 & 21.2 & 15.0 \\
\hline Number of days with temperature over $25^{\circ} \mathrm{C}$ & 0 & 12 & 2.5 & 1.0 \\
\hline
\end{tabular}

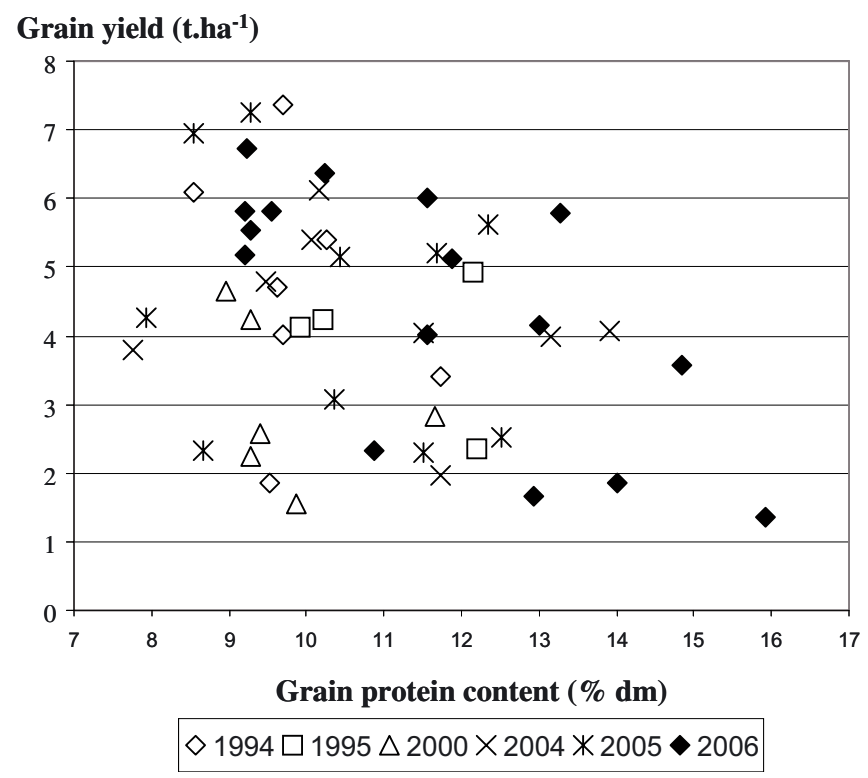

Figure 1. Grain yield (t.ha $\left.{ }^{-1}\right)$ and grain protein content (g per $100 \mathrm{~g}$ ) values for six crop years.

without random effects, the mixed-model method was implemented with linear regression models. Estimates of the relative importance of the variable of interest were used to determine which crop management techniques and environmental conditions had an effect on the limiting factors.

All statistical analyses were performed using the statistical program R (version 2.5.1, 2007).

\section{RESULTS AND DISCUSSION}

\subsection{Variation in grain yield and grain protein content}

Grain yield varied from 1.3 to 7.4 t.ha $^{-1}$ and grain protein content from 7.8 to $15.9 \% \mathrm{dm}$ (Tab. II). These wide ranges of values are usual for organic wheat (David et al., 2005) and wider than in conventional wheat (Leterme et al., 1994).

The values of grain yield and grain protein content are shown in Figure 1. The highest yield values were generally obtained when grain protein content values were low and the highest grain protein content values were observed for the lowest yield values, pointing out the well-known negative correlation between yield and grain protein content (Fowler, 2003). In our study, the coefficients of variation of grain protein content and grain yield were high; namely, $17 \%$ and $38 \%$, respectively.

\subsection{Characteristics of the limiting factors}

A correlation matrix was computed for the quantitative factors, i.e. Nitrogen Nutrition Index, weed density, water balance, photothermal quotient, foliar diseases and high temperatures, and indicated no significant correlation among them (data not shown).

\subsubsection{Abiotic factors}

The water balance values showed water stress during the grain-filling period, as they ranged from 0 to $-213 \mathrm{~mm}$ (Tab. II). This was consistent with the observations reported by David et al. (2005) for the same region. The number of days with an average temperature above $25^{\circ} \mathrm{C}$ after flowering ranged from 0 to 12 (Tab. II). The highest average temperatures were obtained in 2004 and high temperatures were more frequent in the Plain of Valence compared with the other areas. The photothermal quotient during the grain-filling period

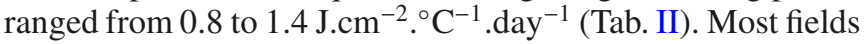
$(75 \%)$ were characterized by a favorable soil structure with an open internal state of clods which would not be expected to limit plant growth or nutrition. At flowering, the Nitrogen Nutrition Index (NNI) varied from 0.25 to 0.71 with a mean of $0.50 \pm 0.12$, indicating frequent and severe nitrogen deficiencies (Tab. II). These values were in the same range as the results reported by David et al. (2005) on organically grown wheat, but were in general lower than those obtained from conventionally grown wheat (Justes et al., 1997).

\subsubsection{Biotic factors}

At flowering, the averaged weed density per plot varied widely from 0 to 567 plants. $\mathrm{m}^{-2}$ with a high coefficient of variation (103\%), expressing high variability among fields (Tab. II). These values were in the same range as those reported in previous organic farming surveys (Rasmussen, 2004; 
Table III. Estimated parameter values and relative importance values $\left(w_{+}(x)\right.$ : probability that a given predictor will appear in the AIC-best model, derived from the mixed-model analysis) of the limiting factors of grain protein content.

\begin{tabular}{lcc}
\hline Limiting factor & $\begin{array}{c}\text { Estimated parameter } \\
\text { value }\end{array}$ & $\begin{array}{c}\text { Relative importance } \\
\text { value } w_{+}(x)\end{array}$ \\
\hline Baking quality grade & -2.4 & 1.00 \\
Nitrogen nutrition index & 5.0 & 0.99 \\
Weed density & 0.004 & 0.88 \\
Photothermal quotient & -1.8 & 0.70 \\
High temperatures & -0.07 & 0.68 \\
Water balance & 0.004 & 0.68 \\
Foliar diseases & -0.003 & 0.39 \\
Soil structure & -0.02 & 0.28 \\
\hline
\end{tabular}

David et al., 2005). Weed density in organic fields is known to be higher than in conventional fields and associated with an increase in the number of species (Hald, 1999; Bond and Grundy, 2001). The overall percentage of leaf area affected by foliar diseases was highly variable from one field to another and varied from 0 to $90 \%$ with a mean of $21.2 \%$ (Tab. II), suggesting low disease pressure. The range of the levels of attacks was wider, and Septoria spp. and Puccinia triticina were more frequent with more severe injuries on leaves in our field survey than in the study of David et al. (2005). This is due to the large range of weather conditions that occurred across our field survey.

\subsection{Identification of the limiting factors of the grain protein content}

\subsubsection{Identification and ranking of the limiting factors}

The relative importance values of each limiting factor $\left(w_{+}(x)\right)$ are presented in Table III. The lowest relative importance values were obtained for soil structure and foliar diseases; respectively, equal to 0.28 and 0.39 . The probability that these factors appear in the best model was thus low and they were assumed to have little effect on grain protein content. Nonetheless, leaf brown rust was involved in increasing grain protein content in previous conventional experimental studies (Debaeke et al., 1996). Our results support the view that foliar diseases were not a major determining factor of grain protein content in organic cereals in the studied region even in the absence of direct disease control. This could be explained by a naturally low disease pressure in the region and the use of tolerant cultivars to Puccinia triticina and Septoria tritici, which helped limit the disease attack levels. The small effect of soil structure on grain protein content in our study was explained by the limited number of fields with an unfavorable soil structure. In other words, with regard to the other limiting factors tested in this study, soil structure and foliar diseases were not major ones in this region.

The relative importance values associated with the other factors were higher than 0.68 . The most important factor was the baking quality grade, followed by the Nitrogen Nutrition
Index and the weed density. Photothermal quotient, water balance and high temperatures had a smaller effect on grain protein content. Here, nitrogen nutrition had a great positive effect on grain protein content of organically grown wheat, confirming results obtained through agronomic diagnosis on conventional cereal (Le Bail and Meynard, 2003). Weed density at flowering had a significant positive effect on grain protein content. Compared with yield-limiting factors (David et al., 2005), no effect of soil structure on grain protein content was found here, but effects of baking quality grade, photothermal quotient and water balance were found. Thus, limiting factors of yield and grain protein content differed slightly, involving different crop management in order to achieve either high yield or high grain protein content.

\subsubsection{Baking quality grade}

The baking quality grade effect of wheat cultivars was tested through the effect of the superior cultivar class. In this study, the baking quality grade was considered as a descriptor and combined with the limiting factors, even if it is a crop management technique, because this characteristic is supposed to have a great effect on grain protein content (Fowler, 2003). Superior cultivars showed a strong negative effect, decreasing grain protein content $\left(w_{+}(x)=1.00\right)$ (Tab. III). This result is consistent with those of Fowler (2003) who showed that superior cultivars had lower grain protein content, here $2.4 \% \mathrm{dm}$ less, than improved cultivars. Thus, the main factor explaining the grain protein content variation was a characteristic of the crop management. Farmers could easily improve the grain protein content of wheat by sowing BAF cultivars.

\subsubsection{Nitrogen nutrition}

The Nitrogen Nutrition Index at flowering (NNI) had a positive effect on grain protein content $\left(w_{+}(x)=0.99\right)$ with a high parameter value (Tab. III). This result showed that nitrogen nutrition was determinant for $\mathrm{N}$ accumulation in grains during the grain-filling period. This is consistent with many previous analytical studies on conventional and organic cereals about the effect of nitrogen nutrition on grain protein content (Debaeke et al., 1996; Justes et al., 1997; Fowler, 2003; Lueck et al., 2006). Among a wide range of potential limiting factors, nitrogen was the first environmental factor explaining the variability in organic winter wheat grain protein content.

\subsubsection{Weed competition}

Weed competition was estimated by weed density at flowering in our study and it had a positive effect on grain protein content $\left(w_{+}(x)=0.88\right)(\mathrm{Tab}$. III). The estimated parameter value was equal to 0.004 , i.e. an increase of 100 plants. $\mathrm{m}^{-2}$ increased the grain protein content by $0.4 \% \mathrm{dm}$. Moreover, the effect of weeds on grain protein content of conventional cereal can vary across studies, being either negative, positive 
or non-existent (Mason and Madin, 1996; Awan et al., 2001; Le Bail and Meynard, 2003). Thus, the effect of weeds should differ, depending on soil and climatic conditions and/or composition of weed flora. Our results showed that the weed density represents an important factor, when considered among a wide range of potential limiting factors for grain protein content in organic systems (third most important limiting factor, Tab. III). However, there is still a need for further research to understand the effect of weeds on grain protein content and determine whether it is negative or positive.

\subsubsection{Climatic limiting factors: radiation, temperature and water availability}

The photothermal quotient calculated for the 30 days after flowering, involving radiation and temperature, had a negative effect on grain protein content (Tab. III). This negative effect confirmed that low radiation and/or high temperature enhanced N content in grains (Sofield et al., 1977; Singh and Jenner, 1984) even in farmers' fields where several other limiting factors occurred at the same time. The negative effect of the number of days over $25^{\circ} \mathrm{C}$ from flowering to harvest on grain protein content (Tab. III) was not consistent with the findings of Bhullar and Jenner (1985). Hence, the negative effect of the photothermal quotient was perhaps more due to low radiation than to high temperatures.

As water balance during the grain-filling period had a positive effect on grain protein content, it means that water deficit after flowering had a negative one on grain protein content (Tab. III). This may be explained by the fact that an increase in available water can increase crop $\mathrm{N}$ uptake (Clarke et al., 2001). However, the assumption made on soil water availability at sowing may involve a wrong estimation of the water balance and also explain this result.

\subsection{Effect of crop management and environmental conditions on limiting factors}

The crop management techniques and environmental conditions tested for each limiting factor are displayed in Table IV.

\subsubsection{Effect of crop management and environmental conditions on the indicators of climatic limiting factors}

The lowest Akaike Information Criteria were obtained with the linear mixed-effects model for high temperature and water balance during the grain-filling period, showing a year effect for those variables. In contrast, no year effect was found for the photothermal quotient during the grain-filling period. The most important crop management techniques and environmental conditions explaining climatic limiting factors were sowing date, earliness at heading, location and soil type (Tab. IV).

During the grain-filling period, weather differences between sub-areas had an effect on the number of days with high temperatures and on the water balance (Tab. IV). In the Plain of Lyon and in the Plain of Valence, the days with temperature over $25^{\circ} \mathrm{C}$ were more frequent, and water balance was lower, hence increasing the water stress. This is consistent with the fact that the plains were drier and warmer than the hilly region of Diois during the grain-filling period. Late sowing delayed the flowering date, involving an increase in the number of days after flowering with high temperature and, in turn, a decrease in the photothermal quotient (Tab. IV). On the other hand, an early sowing date led to an earlier date of flowering and thus an earlier grain-filling period, avoiding water stress in such cases and explaining the strong positive effect of the sowing date on water balance (Tab. IV). This was consistent with the fact that water balance was negatively related to late earliness at heading, as earlier heading helped avoid water stress during the grain-filling period. Water balance was higher in soils $\mathrm{B}$ and $\mathrm{C}$ with deep water reserve, compared with soil D with limited water reserve (Brisson et al., 1992).

\subsubsection{Effect of crop management and environmental conditions on the nitrogen nutrition index}

Linear models were used for analyzing the nitrogen nutrition index (NNI) because there was no year effect (Tab. IV). Preceding $\mathrm{N}_{2}$-fixing fodder crops (mainly lucerne) improved the NNI (Tab. IV). This is consistent with previous studies that showed that the previous crop strongly influenced the time and amount of N release (Debaeke et al., 1996; Dawson et al., 2008). The effect of the previous crop on wheat $\mathrm{N}$ status was more expressed in such organic crops where a small amount of $\mathrm{N}$ was applied. Improved cultivars had a higher NNI than superior cultivars in our study (Tab. IV). The NNI was not strongly related to the $\mathrm{N}$ input applied. This may be due to limited N-use efficiency from organic fertilizers, and the lack of synchronization of crop nitrogen requirements and availability of soil nitrogen from organic manure (Dawson et al., 2008).

Thus, the NNI was more dependent on the previous crop than on $\mathrm{N}$ applied, contrasting with results usually observed in conventional systems where input levels and $\mathrm{N}$ availability are higher. Moreover, spring fertilization before the 2nd node stage had no significant effect on grain protein content in our study. In order to improve grain protein content in organic winter wheat, we would recommend increasing the NNI by including $\mathrm{N}_{2}$-fixing fodder crops and a better management of fertilization strategies.

\subsubsection{Effect of crop management and environmental conditions on weed density}

Mixed-effects models were used for analyzing weed density because the year effect was significant (Tab. IV). Early or late sowing both increased weed density at flowering compared with optimum sowing date (Tab. IV). Early sowing gives an advantage to the weeds as they settle before the crop does. Late sowing is known to enhance weed density, because it furthers 


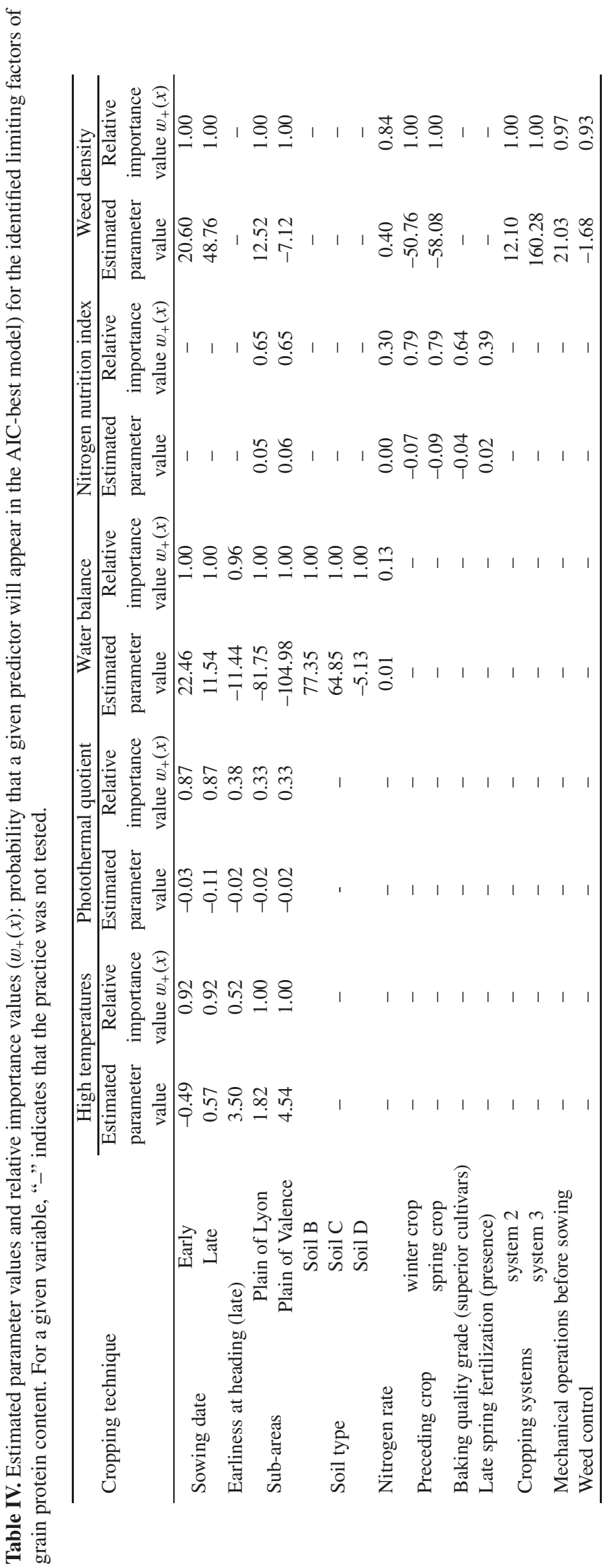


low crop emergence and weed competition in the seedbed (Bond and Grundy, 2001). However, the effect of sowing date on weed density cannot be generalized as it depends on the species and the location of the fields (Bàrberi, 2002).

Weed density was decreased when the previous crops were either winter crops or spring crops compared with fodder legume crops (Tab. IV). Indeed, alternation between winter and spring crops prevents the establishment of a specialized flora and helps keep a low density of each species in addition to diversification of soil tillage reducing weed emergence (Bàrberi et al., 1997).

The cropping system 2 , the intensive one, increased weed density (parameter value equal to 12.1 in Tab. IV), which could be explained by inefficient weed control in the crop rotation. The cropping system 3 , the extensive one, also increased weed density at flowering but with a greater effect (parameter value equal to 160.3 in Tab. IV). This increased weed density was explained by less weed control during the crop rotation. The Plain of Lyon included fields from cropping system 2 or 3 , thus explaining the positive effect of this sub-area on weed density. The Plain of Valence sub-area mainly involved spring and winter preceding crops (data not shown), explaining the negative effect of this area on weed density (Tab. IV).

The positive effect of the nitrogen rate on weed density (Tab. IV) could be explained by better nutritive conditions for weed development (Awan et al., 2001). Moreover, Miyazawa et al. (2004) showed that the weed density was increased by application of manure compost inducing import of weed seeds. Weed density was slightly decreased by the number of weed controls: 1.68 plants. $\mathrm{m}^{-2}$ per weed control operation (Tab. IV), showing, in this study, no important effect of mechanical weed control during crop growth on weed density observed at flowering. As weed control efficacy is known to depend on the species, timing of application and soil conditions (Bond and Grundy, 2001; Bàrberi, 2002), weed control in the studied plots might have not been optimized. Weed density was increased when the number of mechanical operations before sowing increased (Tab. IV), suggesting that repetitive soil tillage may have been applied at inappropriate periods or when potential weed pressure of the field was already too high.

As a conclusion, it is rather difficult to conclude from this study what is the best combination of cropping techniques to manage weed density. Nevertheless, weed density in organic winter wheat fields should be managed by using a false seedbed, optimizing harrowing (timing and number of applications), and alternating spring and winter crops. Further experiments are needed to determine the best combination of cropping techniques.

\section{CONCLUSION}

The variability in the organic wheat grain protein content was mainly explained by three factors in the studied area; the baking quality grade of the cultivar, the nitrogen nutrition index at flowering, and weed density at flowering. These factors all showed a positive effect on grain protein content with high relative importance values of $1.00,0.99$ and 0.88 , respectively.
This study gave a new ranking of limiting factors of organic winter wheat grain protein content in comparison with previous studies. Our results also illustrated the interest of an innovative statistical method, the mixed-model method, for carrying out a regional agronomic diagnosis.

The influence of the cropping techniques was analyzed and the results showed that organic wheat grain protein content could be increased by using a better fertilization management, improved baking quality grade cultivars, fodder $\mathrm{N}$-fixed legume crops as preceding crop, and avoiding late sowing dates. These techniques could help organic farmers to improve the quality of their wheat production in a sustainable way.

Acknowledgements: The authors gratefully acknowledge funding from the European Community financial participation under the Sixth Framework Program for Research, Technological Development and Demonstration Activities, for the Integrated Project QUALITYLOWINPUTFOOD, FP6-FOODCT-2003- 506358. The work of D. Makowski was partially funded by the ANR (French Agency for Research) grant JCJC. We would like to thank D. Gouache (ARVALIS-Institut du Végétal) for his assistance and the technical team of UMR211 INRA AgroParisTech. We would like to give special thanks to Y. Gautronneau and J. Peigné, and also to the organic farmers. We also thank Alan Scaife for his editorial work in English.

\section{REFERENCES}

Akaike H. (1974) A new look at the statistical model identification, IEEE T. Automat. Contr. 19, 716-723.

Audsley E., Milne A., Paveley N. (2005) A foliar disease model for use in wheat disease management decision support systems, Ann. Appl. Biol. 147, 161-172.

Awan N.A., Murdoch A.J., Gooding M.J. (2001) Interaction of N, herbicides and weeds for the grain yield and breadmaking quality of wheat, Asp. Appl. Biol. 64, 165-166.

Bàrberi P. (2002) Weed management in organic agriculture: are we addressing the right issues? Weed Res. 42, 177-193.

Bàrberi P., Silvestri N., Bonari E. (1997) Weed communities of winter wheat as influenced by input level and rotation, Weed Res. 37, 301313.

Bhullar S.S., Jenner C.F. (1985) Differential responses to high temperatures of starch and nitrogen accumulation in the grain of four cultivars of wheat, Aust. J. Plant Physiol. 12, 363-375.

Bond W., Grundy A.C. (2001) Non-chemical weed management in organic farming systems, Weed Res. 41, 383-405.

Brisson N., Seguin B., Bertuzzi P. (1992) Agrometeorological soil water balance for crop simulation models, Agr. Forest. Meteorol. 59, 267287.

Burnham K.P., Anderson D.R. (2002) Model selection and multimodel inference: a practical information-theoretic approach, SpringerVerlag, New York.

Clarke M.P., Gooding M.J., Semenov M.A. (2001) The effect of timing of water availability on soil nitrogen, nitrogen uptake and grain protein concentration of winter wheat, Asp. Appl. Biol. 64, 103-110.

Cousens R. (1985) A simple model relating yield loss to weed density, Ann. Appl. Biol. 107, 239-252.

David C., Jeuffroy M.-H., Henning J., Meynard J.-M. (2005) Yield variation in organic winter wheat: a diagnostic study in the Southeast of France, Agron. Sustain. Dev. 25, 213-223.

David C., Joud S., Bauer L. (2007) Maîtrise de la qualité des blés biologiques à l'échelle d'un bassin d'approvisionnement. Incidence des conditions de production sur les performances des blés biologiques, Programme Recherche INRA-CIAB / ACTA / ACTIA 2005-2007, Lyon. 
Dawson J.C., Huggins D.R., Jones S.S. (2008) Characterizing nitrogen use efficiency in natural and agricultural ecosystems to improve the performance of cereal crops in low-input and organic agricultural systems, Field Crop. Res. 107, 89-101.

Debaeke P., Aussenac T., Fabre J.L., Hilaire A., Pujol B., Thuries L. (1996) Grain nitrogen content of winter bread wheat (Triticum aestivum L.) as related to crop management and to the previous crop, Eur. J. Agr. 5, 273-286.

Doré T., Sebillotte M., Meynard J.-M. (1997). A Diagnostic Method for Assessing Regional Variations in Crop Yield, Agr. Syst. 54, 169188.

Fischer R.A. (1985) Number of kernels in wheat crops and the influence of solar radiation and temperature, J. Agr. Sci. 105, 447-461.

Fowler D.B. (2003) Crop nitrogen demand and grain protein concentration of spring and winter wheat, Agron. J. 95, 260-265.

Gautronneau Y., Manichon H. (1987) Guide méthodique du profil cultural, Lyon.

Gooding M.J., Davies W.P., Thompson A.J., Smith S.P. (1993) The challenge of achieving breadmaking quality in organic and low input wheat in the UK - A review, Asp. Appl. Biol. 36, 189-198.

Grundy A.C., Boatman N.D., Froud Williams R.J. (1996). Effects of herbicide and nitrogen fertilizer application on grain yield and quality of wheat and barley, J. Agr. Sci. Cambridge 126, 379-385.

Hald A.B. (1999) Weed vegetation (wild flora) of long established organic versus conventional cereal fields in Denmark, Ann. Appl. Biol. 134, 307-314.

Justes E., Jeuffroy M.H., Mary B. (1997) The nitrogen requirement of major agricultural crops. Chapter 4: Wheat, barley and durum wheat, in: Lemaire G. (Ed.), Diagnosis of N status in crops, SpringerVerlag, Heidelberg, Germany, pp. 73-91.

Le Bail M., Meynard J.M. (2003) Yield and protein concentration of spring malting barley: the effects of cropping systems in the Paris Basin (France), Agronomie 23, 23-27.

Leterme P., Manichon H., Roger-Estrade J. (1994) Analyse intégrée des rendements du blé tendre et de leurs causes de variation dans un réseau de parcelles d'agriculteurs du Thymérais, Agronomie 14, 341-361.

Lueck L., Schmidt C.S., Cooper J.M., Hall C.M., Shotton P.N., Leifert C. (2006) Effect of organic, low-input and conventional production systems on yield and quality of winter wheat, Asp. Appl. Biol. 80, $135-140$.
Mäder P., Fliessbach A., Dubois D., Gunst L., Fried P., Niggli U. (2002) Soil Fertility and Biodiversity in Organic Farming, Science 296, 1694-1697.

Mason M.G., Madin, R.W. (1996) Effect of weeds and nitrogen fertiliser on yield and grain protein concentration of wheat, Aust. J. Exp. Agr. 36, 443-450.

Miyazawa K., Tsuji H., Yamagata M., Nakano H., Nakamoto T. (2004) Response of weed flora to combinations of reduced tillage, biocide application and fertilization practices in a 3-year crop rotation, Weed Biol. Manag. 4, 24-34.

Peigné J., Call B.C., Roger-Estrade J., David C. (2007) Is conservation tillage suitable for organic farming? A review, Soil Use Manage. 23, 129-144.

Pinheiro J.C., Bates D.M. (2000) Mixed-effects models in S and S-PLUS, Springer, New-York.

Rasmussen I.A. (2004) The effect of sowing date, stale seedbed, row width and mechanical weed control on weeds and yields of organic winter wheat, Weed Res. 44, 12-20.

Reganold J.P., Glover J.D., Andrews P.K., Hinman H.R. (2001), Sustainability of three apple production systems, Nature 410, 926930.

Singh B., Jenner C.F. (1984) Factors controlling endosperm cell number and grain dry weight in wheat: effects of shading on intact plants and of variation in nutritionnal supply to detached, cultured ears, Aust. J. Plant Physiol. 11, 151-163.

Sofield I., Wardlaw I.F., Evans L.T., Zee S.Y. (1977) Nitrogen, phosphorus and water contents during grain development and maturation in wheat, Aust. J. Plant Physiol. 4, 799-810.

Tilman D., Cassman K.G., Matson P.A., Naylor R., Polasky S. (2002) Agricultural sustainability and intensive production practices, Nature 418, 671-677.

van Bruggen A.H.C. (1995) Plant Disease Severity in High-Input Compared to Reduced-Input and Organic Farming Systems, Plant Dis. 79, 976-984.

Whittingham M.J., Stephens P., Bradbury R.B., Freckleton R.P. (2006) Why do we still use stepwise modelling in ecology and behaviour? J. Anim. Ecol. 75, 1182-1189.

Wilkinson A., Young D., Cooper J.M., Wilkockson S., Leifert C. (2006) Effect of fertility management and variety choice on yield and baking quality of organic spring and winter wheat, Asp. Appl. Biol. 80, $147-151$. 